\title{
PKM REMAJA SADAR GIZI DI SEKOLAH MENENGAH PERTAMA (SMP) GATRA DESA KOHOD TANGERANG TAHUN 2019
}

\author{
Yulia wahyuni dan Ety Nurhayati \\ Program Studi Gizi, Fakultas Ilmu-Ilmu Kesehatan, Universitas Esa Unggul \\ E-mail : yulia.wahyuni@esaunggul.ac.id
}

\begin{abstract}
ABSTRAK
Masa remaja (adolescence) merupakan masa transisi atau peralihan dari masa anak-anak menuju dewasa yang ditandai adanya perubahan fisik, psikis dan psikososial (Dieny, 2014). Masa Remaja merupakan masa dimana organ reproduksi mulai berfungsi. Remaja Putri akan mengalami mentruasi sedangkan remaja putra mengalami mimpi basah (Proverawati, 2009). Tujuan kegiatan pengabdian masyarakat ini adalah memberikan edukasi kepada remaja tentang Gizi seimbang sehingga meningkatkan kesadaran mereka akan pentingnya gizi (RADARZI). Sasaran utama kegiatan pengabdian masyarakat ini adalah Remaja putri SMP Gatra Desa Kohod, Kabupaten Tangerang berjumlah 98 orang siswi. Kegiatan pengabdian masyarakat ini dilakukan pada bulan Maret hingga November 2019. Metode yang digunakan yaitu penyuluhan dengan ceramah, permainan ular tangga RADARZI dan demo masak. Hasil kegiatan pengabdian masyarakat ini adalah 1) terjadi peningkatan pengetahuan responden tentang gizi seimbang dengan kategori baik dari $14 \%$ menjadi $90 \%$. 2) penurunan masalah status gizi kurang dari $15 \%$ menjadi $3 \%, 3$ ) terjadi penurunan masalah anemia pada responden dari $30 \%$ menjadi $16 \%$, 4) siklus menstruasi oligomenore melami penurunan dari $10 \%$ menjadi $8 \%$.
\end{abstract}

Kata kunci : remaja, RADARZI, status gizi, siklus mentruasi

\section{PENDAHULUAN}

Pencapaian pembangunan sumber daya manusia yang berkualitas, sehat cerdas dan produktif merupakan tantangan utama dalam pembangunan suatu bangsa. Masalah gizi menjadi bagian pencetus kualitas SDM. Masalah Gizi Indonesia dilanda oleh masalah gizi ganda yaitu gizi lebih dan juga gizi kurang. Masalah gizi dapat terjadi pada seluruh kelompok umur, bahkan masalah gizi pada suatu kelompok umur tertentu akan mempengaruhi keadaan gizi pada siklus kehidupan berikutnya (intergenerational impact) (Hanson et al, 2015). Masa kehamilan merupakan periode yang sangat menentukan kualitas SDM di masa depan, karena tumbuh kembang anak sangat ditentukan oleh kondisinya saat masa janin dalam kandungan. Akan tetapi perlu diingat bahwa keadaan kesehatan dan status gizi ibu hamil ditentukan juga jauh sebelumnya, yaitu pada saat remaja atau usia sekolah (Branca et al, 2015). Dampak masalah gizi pada periode 
remaja (persiapan hamil) cenderung melahirkan bayi dengan status BBLR yang akan menyebabkan stunting (Branca et al, 2015).

Masa remaja (adolescence) merupakan masa transisi atau peralihan dari masa anak-anak menuju dewasa yang ditandai adanya perubahan fisik, psikis dan psikososial (Dieny, 2014). Menurut World Health Organisation (WHO) batasan kelompok usia remaja adalah usia 12-24 tahun sedangkan menurut Depkes RI, batasan kelompok usia remaja adalah usia 10-19 tahun dan belum menikah (Kemenkes, 2013). Masa Remaja merupakan masa dimana organ reproduksi mulai berfungsi. Remaja Putri akan mengalami mentruasi sedangkan remaja putra mengalami mimpi basah (Proverawati, 2009). Berdasarkan data BKKBN tahun 2014, di Indonesia jumlah remaja berusia 10-24 tahun di Indonesia sudah mencapai sekitar 64 juta atau $27,6 \%$ dari total penduduk Indonesia (Kemenkes, 2014). Pemenuhan kebutuhan gizi pada masa remaja dapat memaksimalkan kerja organ reproduksi yang akan berlanjut pada hasil konsepsi (Hanson et al, 2015 ; Branca et al, 2015). Hasil penelitian Lestari, W (2014)menunjukkan bahwa orang tua dengan masalah gizi (perawakan pendek) beresiko 11,13 kali melahirkan anak dengan keadaan stunting. Hasil penelitian Ulfani, D,H(2011) menunjukkan bahwa faktor penyebab stunting adalah pendidikan Ibu.

Masa remaja merupakan masa pencarian identitas sehingga remaja cepat terpengaruh oleh lingkungan. Kecemasan akan bentuk tubuh membuat remaja sengaja mengurangi asupan makan bahkan ada yang memilih tidak makan seharian atau lebih (Ulfani dkk, 2011). Kebiasaan ini dapat mengakibatkan remaja mengalami kerawanan pangan yang berhubungan dengan asupan zat gizi yang rendah dan berisiko pada kesehatannya termasuk anemia. Berdasarkan Riskesdas tahun 2007 prevalensi anemia remaja usia $\leq 14$ tahun di Indonesia sebanyak 12,8\%.Sekitar sepertiga remaja dan WUS menderita anemia gizi besi. Bila masalah ini tidak tertanggani maka akan berlanjut pada masa kehamilan. Anemia gizi besi dijumpai pada $40 \%$ ibu hamil. Kekurangan Energi Kronis (KEK) dijumpai pada WUS yang ditandai dengan proporsi LILA $<23.5$ (Salimar et al, 2009). Pada umumnya proporsi WUS dengan risiko KEK cukup tinggi pada usia muda (15-19 tahun), kondisi 
ini memprihatinkan mengingat WUS dengan risiko KEK cenderung melahirkan bayi BBLR yang akhirnya akan menghambat pertumbuhan pada anak usia balita (stunting) (Arumsari, 2008).

Anemia adalah penurunan kuantitas sel-sel darah merah dalam sirkulasi atau jumlah hemoglobin berada dibawah batas normal. Anemia dapat menimbulkan berbagai dampak pada remaja antara lain menurunkan daya tahan tubuh sehingga mudah terkena penyakit, menurunnya aktivitas dan prestasi belajar karena kurangnya konsentrasi (American Society of Hematology, 2013). Anemia defisiensi besi merupakan anemia yang paling sering terjadi pada remaja, karena kebutuhan yang tinggi untuk pertumbuhan. Anemia kurang zat besi lebih banyak terjadi pada remaja putri dibanding remaja putra (Heather et al, 2009). Data Survei Kesehatan Rumah Tangga (SKRT) tahun 2004 menyatakan bahwa prevalensi anemia gizi pada remaja putri usia (10-18 tahun) $57,1 \%$. Anemia kurang besi dapat dipengaruhi oleh beberapa faktor yaitu, kurangnya mengkonsumsi sumber makanan hewani sebagai salah satu sumber zat besi yang mudah diserap (heme iron), sedangkan bahan makanan nabati (non-heme iron) merupakan sumber zat besi yang tinggi tetapi sulit diserap sehingga dibutuhkan porsi yang besar untuk mencukupi kebutuhan zat besi dalam seharinya. Penyebab lainnya adalah kekurangan zat gizi yang berperan dalam penyerapan zat besi seperti, protein dan vitamin C. Konsumsi makanan tinggi serat, tannin dan phytat dapat menghambat penyerapan zat besi (American Society of Hematology, 2013; Heather et al, 2009). Berdasarkan metanalisis penelitian diketahui bahwa defisiensi besi juga dapat terjadi pada remaja dengan kategori obesitas. Hal ini dikarenakan adanya peningkatan produksi hepcidin yang dapat menghambat penyerapan zat besi (Ana et al, 2011; Karen et al, 2004).

Remaja putri mempunyai pola dan kebiasaan makan homogen sehinga berdampak pada asupan energi dan zat gizi kurang dari angka kecukupan gizi (AKG) yang sudah dianjurkan. Hal ini juga terlihat bahwa hampir separuh remaja putri mempunyai berat badan tidak ideal dan tinggi badan yang kurang dari 150, yang menunjukkan adanya hambatan pertumbuhan (Sayogo, 2011). Berdasarkan hasil 
penelitian yang dilakukan oleh Fanny et al (2010) di Kabupaten Maros pada siswa SMU PGRI diperoleh data yang menunjukkan bahwa asupan energy, karbohidrat, lemak dan protein yang kurang sebanyak $\pm 40 \%$. Adapun persentase asupan vitamin $\mathrm{C}$ dan zat besi (Fe) yang kurang yaitu sebanyak 99,1\% dan 97,3\%. Penelitian tentang status gizi berdasarkan indeks massa tubuh (IMT) yang juga dilakukan oleh Fanny et al (2010) di SMU PGRI Maros menunjukkan bahwa jumlah siswa yang tergolong kurus mencapai $34,5 \%$ yang terdiri atas $9,7 \%$ berstatus gizi kurus tingkat berat.

Beberapa penanganan yang dilakukan dalam menangani masalah gizi remaja adalah peningkatan pengetahuan gizi pada masa remaja dan asupan gizi yang sesuai dengan kebutuhan.

Upaya mengatasi masalah gizi disarankan dilakukan dengan pendekatan yang lebih berkelanjutan dan mempunyai nilai pengembalian ekonomi (economic return) yang relatif tinggi (World Bank 2006), yaitu melalui intervensi pendidikan gizi agar terjadi perubahan perilaku makan sehingga nantinya penurunan prevalensi anemia dapat lebih dicapai. Remaja dapat dikatakan merupakan target ideal pendidikan gizi, karena remaja umumnya bersifat lebih terbuka serta menunjukkan keingintahuan dan ketertarikan terhadap ide atau pengetahuan baru.

Peningkatan pengetahuan gizi remaja tentang gizi seimbang yang kemudian diharapkan dapat memperbaiki sikap serta perilaku makan remaja dapat dilakukan melalui sekolah dengan pertimbangan: 1) remaja menghabiskan sebagian besar waktunya di sekolah dan 2) sekolah memiliki guru Bimbingan dan Konseling (BK) yang berkewajiban memberi bantuan kepada siswa dalam upaya menemukan pribadi, mengenal lingkungan dan merencanakan masa depan atau bimbingan dalam hal pribadi, sosial, belajar dan karier. Berdasarkan pertimbangan di atas perlu dikaji dampak intervensi gizi melalui sekolah, yaitu dengan pendidikan gizi yang akan terbukti dengan pemilihan jenis bahan makanan dan asupan makan remaja setiap hari.

Desa Kohod merupakan salah satu desa di kecamatan Pakuhaji Kabupaten Tangerang. Desa Kohod dijadikan percontohan untuk program kampung sejahtera desa oleh organisasi aksi 
solidaritas era kabinet kerja atau yang disingkat OASE. OASE merupakan organisasi dengan Nirlaba mewadahi serangkaian Program yang mendukung tercapainya Nawacita yang terkait upaya revolusi mental dan yang melibatkan berbagai

Kementrian/institusi/lembaga.Setelah dilakukan survey pendahuluan bersama dengan Tim LPPM Universitas Esa Unggul, remaja putri SMP Garuda Tehnologi Pantura (GATRA) ditemukan data bahwa remaja putri tidak memahami tentang gizi seimbang. Selain masalah tentang gizi seimbang remaja pernah tidak pernah memantaui status gizi dan siklus menstruasi,. Berdasarkan latar belakang dan hasil survey tersebut perlu dilakukan pengabdian masyarakat berupa edukasi Gizi.

Berdasarkan hasil survey dan diskusi dengan mitra, ada beberapa masalah yang dihadapi oleh mitra dalam hal ini adalah remaja putri :

1. Remaja putri tidak pernah dilakukan pemantauan status gizi

2. Remaja putri tidak pernah memantaui kelender menstruasi setiap bulan
3. Rendahnya pengetahuan remaja putri terhadap makanan dengan gizi seimbang serta pentingnya sarapan pagi

Ketiga permasalahan ini terjadi disebabkan oleh beberapa hal anatara lain :

1. Kurangnya pengetahuan remaja putri tentang manfaat dari pemantauan status gizi secara teratur baik dengan melalukan penimbangan barat badan dan tinggi badan maupun dengan pemeriksaan kadar haemoglobin

2. Kurangnya informasi tentang makanan dengan gizi seimbang serta pentingnya sarapan sehat

3. Petugas kesehatan setempat tidak pernah melakukan sosialisasi tentang pemantauan status gizi serta makanan sehata dan gizi seimbang

\section{KHALAYAK SASARAN}

Sasaran dalam kegiatan pengabdian masyarakat ini adalah remaja putri SMP Garuda Tehnologi Pantura (GATRA) Desa Kohod Kabupaten Tangerang. 


\section{METODE PELAKSANAAN KEGIATAN}

\section{Alur Pelaksanaan Kegiatan Pengabdian Masyarakat}

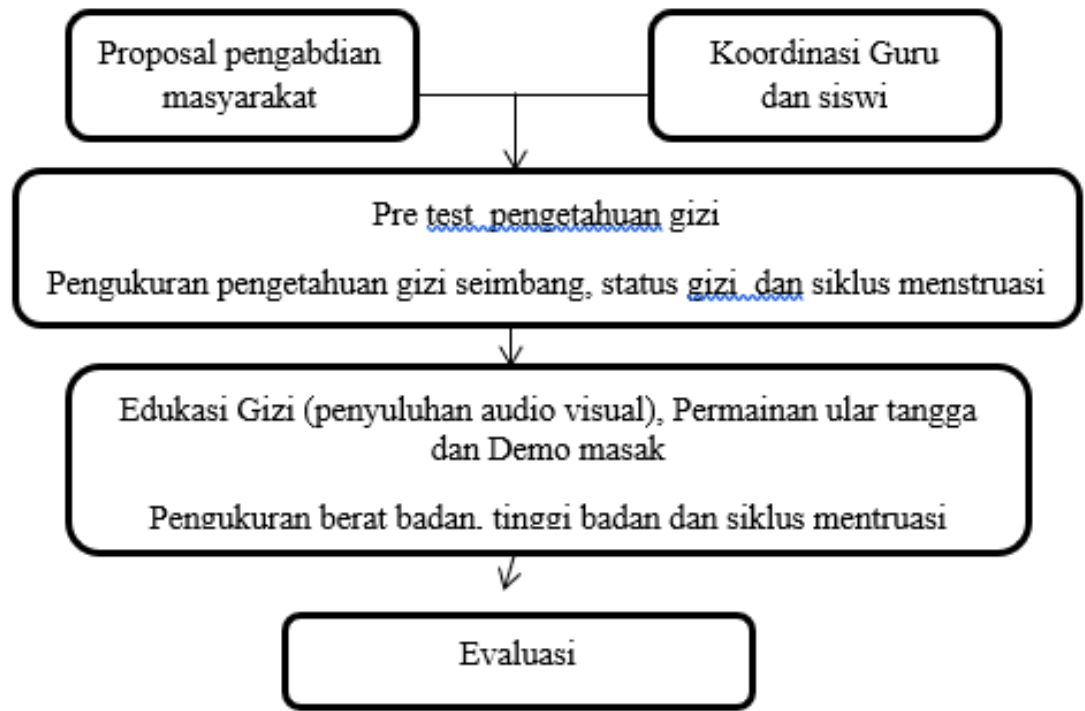

Gambar 1. Alur kegiatan Pengabdian Masyarakat

Pengetahuan gizi seimbang diukur dengan menggunakan kuisioner tentang 4 pilar gizi seimbang yang terdiri dari makanan beraneka ragam, pemantauan berat badan secara teratur, cuci tangan (kebisaan perilaku hidup bersih dan sehat) dan olahraga secara teratur. Selaian pengetahuan gizi seimbang juga dikur tentang penting sarapan pagi.

Data status gizi ada dua yaitu data antropometri dan data kadar haemoglobin. Data antropometri yang diukur yaitu berat badan menggunakan timbangan berat badan digital, tinggi badan menggunakan microtoise. Kadar homoglobin diukur menggunakan easytouch GCU. Data siklus menstruasi diukur dengan menggunakan kelender menstruasi.
Metode yang dilakukan dalam melaksanakan kegiatan pengabdian masyarakat ini adalah

1. Wawancara lansung bagi remaja putri yang mengalami status gizi kurang, anemia dan juga yang siklus mentruasi tidak teratur. Dengan demikian kita bisa mengetahui penyebab dasar dari masalah tersebut. Hal ini menjadi pertimbangan dalam melaksanakan edukasi baik dengan penyuluhan, permainan ular tangga maupun dengan demo memasak.

2. Permainan ular tangga dimainkan secara kelompok. Pemandu permainan oleh remaja putri yang nilai pengetahuan gizi seimbangnya tinggi saat post test 1 . Kelompok 
yang masuk arena permainan dimulai dari start-finish.Setiap melangkah ke kotak ular tangga bila bisa menjawab pertanyaan yang berkaitan dengan 4 pilar gizi seimbang. Permainan ular tangga tetap dijalankan setiap mata pelajaran olahraga yang diawasi lansung oleh guru Penjaskes orkes.

3. Demo masak

Demo masak dilakukan oleh mahasiswa Prodi Gizi Universitas Esa unggul. Menu pada demo masak adalah menu sederhana untuk sarapan pagi dan juga menu makan siang. Pada saat demo masak, setiap bahan makanan yang digunakan mejelaskan kandungan gizinya. Selanjutnya prosedur masaknya.

4. Siklus menstruasi

Hari pertama menstruasi setiap bulan dicatat dalam kalender menstruasi. Pemantauan menstruasi, data antropometri dilakukan oleh dosen yang menjadi tim dalam kegiatan pengabdian masyarakat setiap bulan.

Berikut Jadwal kegiatan pengabdian masyarakat :

Tempat : SMP GATRA desa Kohod Kabupaten tangerang

Waktu : pengabdian masyarakat ini akukan pada tahun 2019

\begin{tabular}{l|l|l|l|l|l|l|l|l|l|l|l|l}
\hline Kegiatan & \multicolumn{10}{c}{ Bulan } \\
\cline { 2 - 10 } & 1 & 2 & 3 & 4 & 5 & 6 & 7 & 8 & 9 & 10 & 11 & 12 \\
\hline Pengambilan data Awal & & & & & & & & & & & & \\
\hline Pemantauan BB, TB & & & & & & & & & & & & \\
\hline Pemantuan menstruasi & & & & & & & & & & & & \\
\hline Pemantauan HB & & & & & & & & & & & & \\
\hline Permaianan ular tangga & & & & & & & & & & & & \\
\hline Demo masak & & & & & & & & & & & & \\
\hline
\end{tabular}

Peserta : Remaja Putri kelas VII dan IX SMP GATRA Desa Kohod kabupaten Tangerang 
HASIL DAN PEMBAHASAN

\section{Pelaksanaan Kegiatan}

Kegiatan pengabdian masyarakat ini dengan judul Remaja sadar gizi pada remaja awal di SMP GATRA Desa Kohod kabupaten Tangerang. Kegiatan pengabdian masyarakat dilaksanakan sejak Maret hingga November 2019. Pelaksanaan kegiatan pengabdian masyarakat ini berlansung dengan baik dan lancar. Peserta dalam kegiatan ini adalah seluruh siswi dari kelas VI sampai IX yang berjumlah 98 siswi. Kegiatan ini melibatkan, dua tim dosen dan 3 orang mahasiswa prodi Gizi Universitas Esa Unggul. Beberapa kegiatan yang dilakukan selama kegiatan pegabdian masyarakat ini adalah:

1. Edukasi gizi melalui penyuluhan dengan metode ceramah

Antusiasme siswi cukup bagus dengan memberikan pertanyaan tentang contoh makanan yang sehat untuk sarapan dan makan siang. Selain itu juga pertanyaan yang lebih menarik yaitu tentang jajanan sehat. Hasil survey menunjukan sebagian besar siswa, menu makanan siangnya hanya dari jajanan yang dijual di sekolah. Setalah dilakukan analisis ke beberapa siswa menunjukkan bahwa tingkat kecukupan zat gizi makronya tidak cukup. Dengan demikian melalui penyuluhan ini, dapat meningkatkan wawasan siswi akan komponen zat gizi dari setiap porsi makan setiap hari serta pemenuhan kebutuhan zat gizi yang dibutuhkan oleh tubuh.

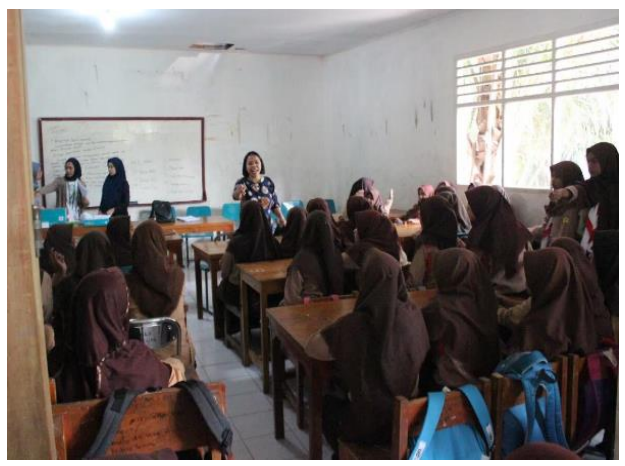

2. Edukasi dengan menggunakan permainan ular tangga RADARZI Permainan Ular tangga radarzi merupakan suatu bentuk permainan yang mekanisme permainan dalam bentuk tim. Instruktur game 2 orang yakni sebagai wasit dan pembaca pertanyaan. Satu kali permainan terdiri dari 2 tim. Pemandu tim yang masuk pertama dalam arena permainan adalah hasil lemparan dadu yang nilainya tinggi. Proses permainan dari titik start sampai finish dengan menjawab pertanyaan. Pertanyaan yang diberikan berkaitan dengan 4 pilar gizi seimbang yaitu makan 
makanan yang beraneka ragam, pemantauan berat badan secara teratur, cuci tangan (kebisaan perilaku hidup bersih dan sehat) dan olahraga secara teratur.satu kali permainan dengan durasi maksimal 15 menit. Semakin banyak pertanyaan yang bisa dijawab maka durasinya akan semakin cepat. Dari hasil kegiatan durasi tercepat hingga ke titik finish adalah 9 menit. Dengan demikian hal ini menunjukkan minat siswa dalam mengikuti permainan ini semakin baik dan juga mereka terpapar dengan topik tentang gizi seimbang

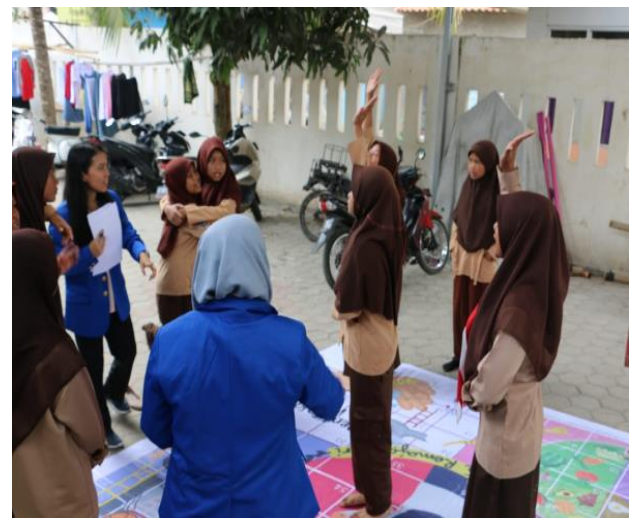

3. Demo masak

Demo masak merupakan salah satu bentuk edukasi gizi memperkenalkan menu sederhana pada siswa serta bahan makanan yang terkandung dalam menu tersebut. Hasil kegiatan demo masak menunjukkan bahwa banyak siswa yang sudah memahami zat gizi dari menu yang yang digunakan serta berinteraksi pada saat demo masak. Hal sebagai bukti bahwa edukasi dalam bentuk penyuluhan dan juga permainan dapat meningkatkan pengetahuan siswa baik tentang bahan makanan maupun zat gizi.

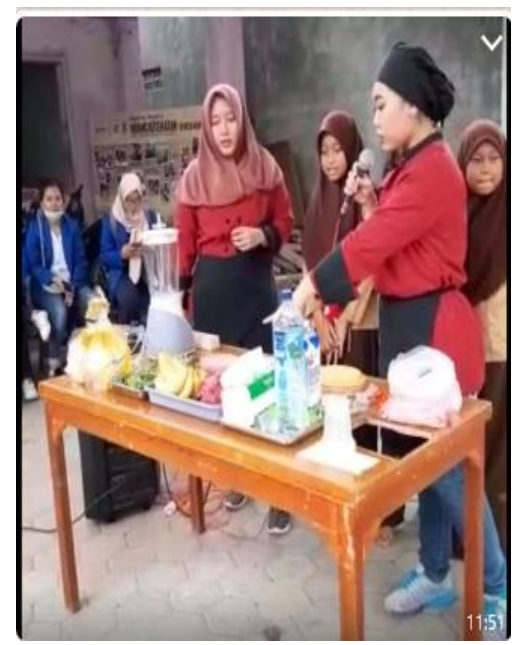

Beberapa parameter yang dinilai sebagai hasil dari kegiatan pengabdian masyarakat ini adalah sebagai berikut :

\section{Pengetahuan}

Sebuah sikap dan perilaku akan terbentuk dari stimulasi berupa materi atau objek tentang sesuatu yang akan menimbulkan pengetahuan baru pada seorang individu. Hasilnya adalah respon yang baik sifatnya bagus ataupun buruk. Hal ini yang sebut tindakan. Dengan demikian tindakan/ perilaku seseorang merupakan 
dampak dari pengetahuan yang dimikili. Meskipun hal ini dibantahkan oleh Notoatmodjo, 2010 yang mengatakan , pengetahuan yang cukup tidak menjamin seseorang berprilaku yang sama seperti apa yang diketahui (Notoatmodjo, 2010). Masalah gizi timbul dikarenakan ketidaktahuan responden dan kurangnya informasi mengenai gizi.

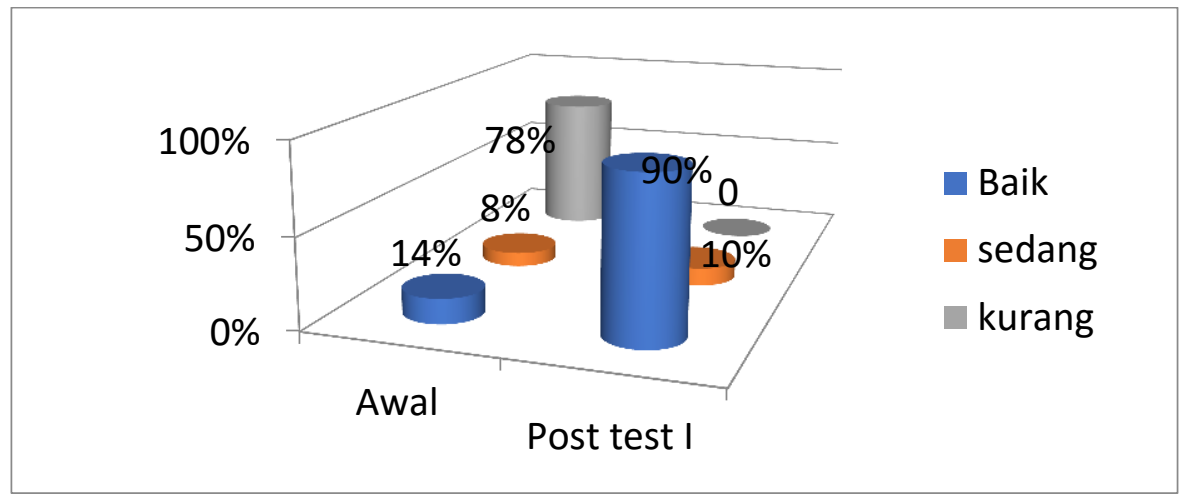

Hasil wawancara pada beberapa siswa sebelum dilakukan pengabdian masyarakat menunjukkan bahwa sebagian besar tidak menyadari akan pentingnya mengkonsumsi makanan yang beragam dan berolahraga yang teratur, PHBS dan penimbangan berat badan yang berkala. Hal ini terbukti dengan hasil analisis data pengetahuan menunjukkan bahwa kategori pengetahuan sebelum dilakukan pengabdian masyarakat didominasi dengan skor pengetahuan yang kurang yakni $78 \%$. Kegiatan pengabdian masyarakat yang melakukan edukasi gizi dalam bentuk penyuluhan, permainan dan juga demo masak dapat meningkatkan pengetahuan siswa. Hasil analisis data pengetahuan post test menunjukkan bahwa kategori pengetahuan didominasi oleh pengetahuan baik sebanyak $90 \%$.

2. Status gizi

Status gizi merupakan keadaan tubuh sebagai akibat antara konsumsi, penyerapan dan penggunaan zat-zat gizi atau keadaan fisiologik akibat dari tersedianya zat gizi dalam tubuh (Supariasa, 2002). Hasil analisis data status gizi sebelum dilakukan kegiatan pengabdian masyarakat menunjukkan bahwa $15 \%$ responden mengalami masalah gizi kurang. 


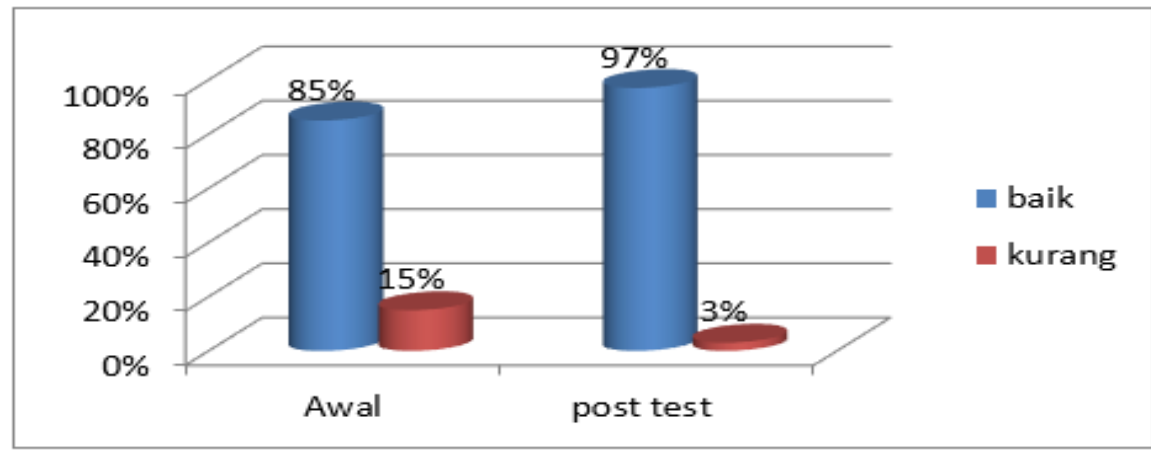

Kegiatan masyarakat ini dapat membawa perubahan baik bagi status gizi responden. Hal ini terbukti dengan penurunan masalah status gizi kurang yaitu $12 \%$. Pengukuran status gizi selain Berat badan badan per umur juga dinilai dengan kadar hemoglobin. Hasil analisis data kadar hemoglobin diawal kegiatan pengabdian masyarakat menunjukkan bahwa sebanyak $30 \%$ responden mengalami anemia. Data tersebut mengalami penurunan pada akhir periode kegiatan pengabdian masyarakat yaitu sebesar $14 \%$.

3. Siklus mestruasi

Gangguan pada $r$
mensturasi dipengaruhi
hormon, kelainan sistemik, stres.
Gangguan mensturasi terdiri dari
tiga, yaitu: siklus mensturasi
pendek yang di sebut dengan
polimenore, siklus mensturasi
panjang atau oligomenore dan
amenore jika tidak menstruasi
dalam 3 bulan berturut -turut

(Isnaeni, 2010). Hasil analis data awal menunjukkan bahwa sebanyak $10 \%$ responden mengali oligomenore. Data ini mengalami penurunan $2 \%$ pada akhir kegiatan pengabdian masyarakat.

Akhir dari kegiatan pengabdian masyarakat ini, kami mengucapkan terima kasih Pihak sekolah SMP Gatra Desa Kohod Kabupaten Tangerang yang memberi kesempatan kepada tim untuk melakukan kegiatan pengabdian masyarakat di sekolah. Kami juga berterima kasih kepada Kemenristek Dikti yang mendanai kegiatan ini.serta Universitas Esa Unggul yang memfasilitasi tim hingga kegiatan ini bisa terselesaikan dengan baik.

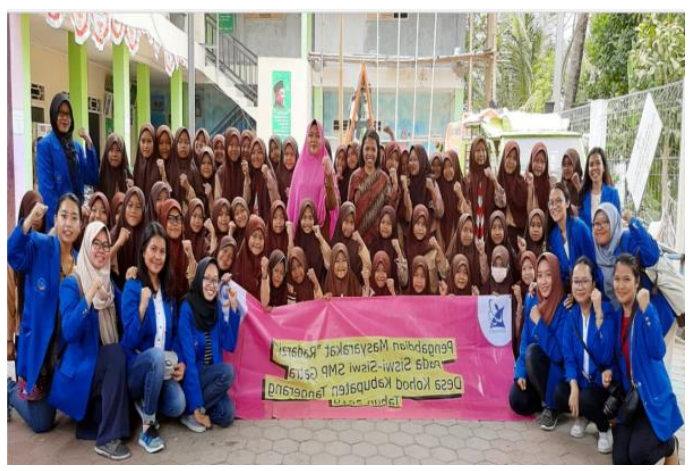



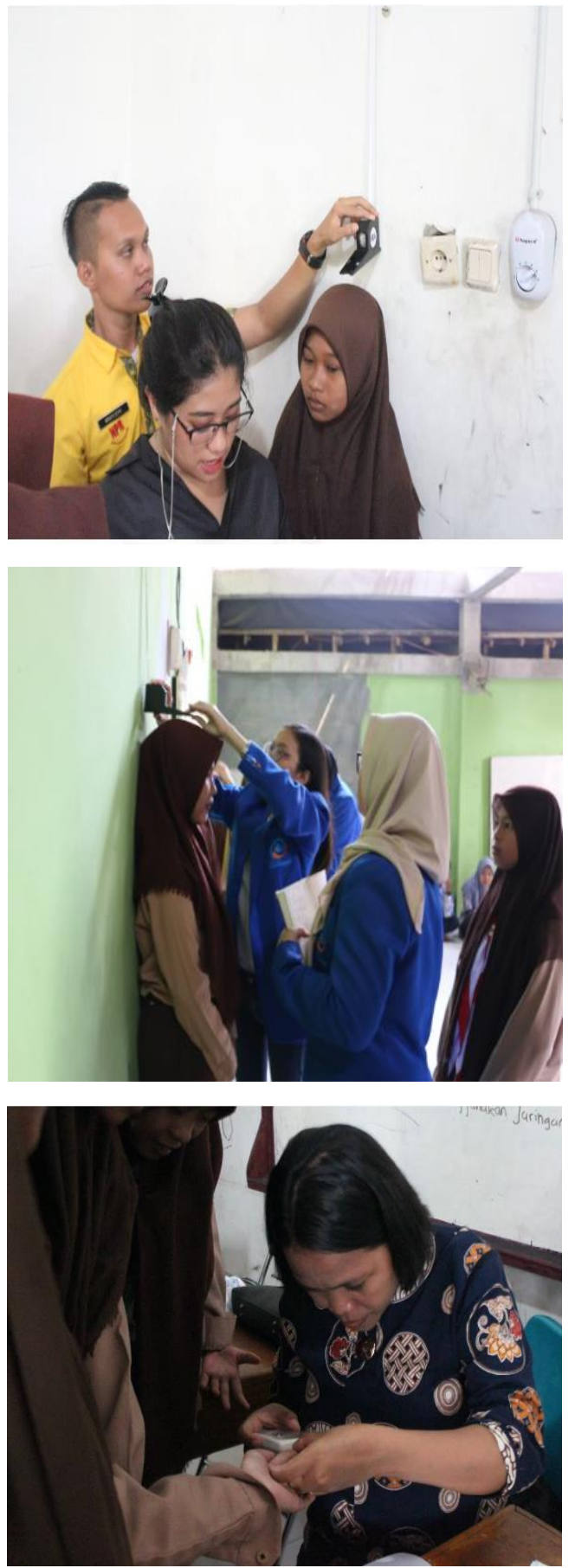

KESIMPULAN

Hasil kegiatan pengabdian masyarakat ini dengan judul Remaja sadar Gizi (RADARZI) pada SMP Gatra Desa Kohod Kabupaten Tangerang tahun 2019 adalah : 1) terjadi peningkatan pengetahuan responden tentang gizi seimbang dengan kategori baik dari $14 \%$ menjadi $90 \%$. 2) penurunan masalah status gizi kurang dari $15 \%$ menjadi $3 \%, 3$ ) terjadi penurunan masalah anemia pada responden dari $30 \%$ menjadi $16 \%, 4$ ) siklus menstruasi oligomenore melami penurunan dari $10 \%$ menjadi $8 \%$. Diharapkan hasil kegiatan masyarakat ini akan menjadi acuan bagi kegiatan pengabdian masyarakat selanjutnya terutama mengenai masalah staus gizi dan juga siklus menstruasi pada remaja/siswi.

\section{DAFTAR PUSTAKA}

Hanson, M. A., Bardsley, A., De-Regil, L. M., Moore, S. E., Oken, E., Poston, L., ... Morris, J. L. 2015. The International Federation of Gynecology and Obstetrics (FIGO) recommendations on adolescent, preconception, and maternal nutrition: "think Nutrition First." International Journal of Gynecology and Obstetrics, 131, S213-S253. https://doi.org/10.1016/S00207292(15)30023-0

Branca, F., Piwoz, E., Schultink, W., \& Sullivan, L. M. artine.2015. Nutrition and health in women, children, and adolescent girls. BMJ (Clinical Research Ed.), 351(November), h4173. https://doi.org/10.1136/bmj.h4173

Lestari, W., Margawati, A., \& Rahfiludin, M. Z. 2014. Faktor 
Risiko Stunting pada Anak Umur 6-24 bulan di Kecamatan Penanggalan Kota Subulussalam Provinsi Aceh. Jurnal Gizi Indonesia, 3(1), 37-45. https://doi.org/10.14710/JGI.3.1.1 26-134

Ulfani, D. H., Martianto, D., Yayuk, D., \& Baliwati, F. 2011. FaktorFaktor Sosial Ekonomi Dan Kesehatan Masyarakat Kaitannya Dengan Masalah Gizi Underweight, Stunted, Dan Wasted Di Indonesia: Pendekatan Ekologi Gizi. Journal of Nutrition and Food Jurnal Gizi Dan Pangan, 6(61), 59-65.

Corwin, Elizabeth J.2009. Handbook of Pathophysiologi, 3rd Ed. Jakarta: EGC.

Riset Kesehatan Dasar.2007. Jakarta : Badan Penelitian Kesehatan Kementrian Kesehatan RI.

Salimar et al. 2009. Karakteristik masalah pendek (stunting) pada balita di seluruh wilayah Indonesia. Jurnal Penelitian Gizi dan Makanan, 3(67), 63-74.

Arumsari, E. 2008. Faktor Risiko Anemia Pada Remaja Putri Peserta Program Pencegahan Dan Penanggulangan Anemia Gizi Besi (Ppagb) Di Kota Bekasi. Skripsi Institut Pertanian Bogor, 21-26

American Society of Hematology. Anemia. 2013. Avalaible from: http:www.hematology.org

Heather A Eicher-Miller, April C Mason, Connie M Weave.2009. Food insecurity is associated with iron deficiency anemia in US Adolescents. Am J Clin Nutr. 90:1358- 71 .
Ana C Cepeda-Lopez et al.2011. Sharply higher rates of iron deficiency in obese Mexican women and children are predicted by obesityrelated inflammation rather than by differences in dietary iron intake. Am J Clin Nutr ;93:975-83.

J, Nead Karen et al.2004. Overweight Children and Adolescence: A Risk Group For Iron Deficienc. Avalaible from: http:www.pediatric.com.

Sayogo, Savitri. 2011. Gizi Remaja Putri. Jakarta: Balai Penerbit Fakultas Kedokteran Universitas Indonesia

Suparias. 2002. Penilaian Status Gizi. Jakarta: EGC.

Fanny, dkk. 2010. Tingkat Asupan Zat Gizi dan Status Gizi Siswa SMU PGRI Kabupaten Maros Propinsi Sulawesi Selatan. Media Gizi Pangan. IX Edisi 1. 15-19.

World Bank. 2006. Repositioning Nutrition as Central to Development. A Strategy for Large - Scale Action. Washington.

Daris, C., Wibowo, T., Notoatmojo, H., \& Rohmani, A. 2013. Hubungan Antara Status Gizi dengan Anemia pada Remaja Putri di Sekolah Menengah Pertama Muhammadiyah 3 Semarang Relationship Between Nutritional Status With Anemia in Young Women in Junior High School of Muhammadiyah 3 Semarang. Jurnal Kedokteran Muhammadiyah, 1(2), 3-7.

Emilia, E. 2009. Pengetahuan, Sikap Dan Praktek Gizi Pada Remaja Dan Implikasinya Pada Sosialisasi Perilaku Hidup Sehat. Media 
Pendidikan, Gizi Dan Kuliner, 1(1), 1-9. Retrieved from http://ejournal.upi.edu/index.php/ Boga/article/viewFile/6276/4268

Dwiriani, C. M., Rimbawan, Hardinsyah, Riyadi, H., \& Martianto, D. 2011. Pengarum Pemberian Zat Multi Gizi Mikro dan Pendidikan Gizi terhadap Pengetahuan Gizi, Pemenuhan Zat Gizi dan Status Besi Remaja Putri. Jurnal Gizi Dan Pangan, 6(3), 171-177.

Indiarti MT.2007. Kehamilan, persalinan dan perawatan bayi. Yogyakarta : Diglossia Media;

Notoatmodjo, S. 2010. Pendidikan dan Perilaku Kesehatan. PT. Rineka Cipta: Jakarta.
Demitri, Athira. 2015. Pengaruh Pendidikan Gizi Tentang Pola Makan Seimbang Melalui Game Puzzle Terhadap Peningkatan Pengetahuan Anak SDN 067690 Kota Medan. Jurnal Gizi FKM Universitas Sumatera Utara.

Riyadi, S, \& Sukarmin. 2009. Asuhan Keperawatan pada Anak. Graha Ilmu, Yogyakarta

Isnaini.2010.Pengaruh Pendidikan Kesehatan terhadap Perubahan Pengetahuan dan Sikap Ibu Tentang KB IUD Di Dukuh Sawahan Wilayah Kerja Puskesmas Weru Sukoharjo 